\title{
Gender Politics and Its Impact on Female Marriage Migration: Women from Former Soviet Union Countries in Japan
}

\section{Viktoriya KIM}

\begin{abstract}
This paper is both a review of the discussion on gender politics in the Soviet Union and Russia, as well as an attempt to examine how such politics have affected women's lifestyle, their ideas on marriage migration and the strategies they use to migrate. It is based on in-depth interviews with women from former Soviet Union countries living in Japan.
\end{abstract}

KEYWORDS: Marriage migration, Women from former Soviet Union countries, Migration to Japan, Gender politics, Gender construction

JEL CLASSIFICATION: F22, J12, J61

\section{INTRODUCTION}

Since the collapse of the Union of Soviet Socialist Republics ${ }^{1}$, approximately 10 percent of its former citizens (or 28 million out of a total of 287 million in the last Soviet census of 1989) have moved to another country (Laruelle, 2013b, p. 6). Women represent a majority of emigrants, with most of these being younger women of childbearing age (Kivisto \& Faist, 2010, p. 60). However, hitherto not much attention has been paid to the issues and problems they face by major international studies on migration (Laruelle, 2013b, p. 6), not to mention that there is a dearth of scholarly research on Russian women marriage migration. This paper aims to analyze how the historical background and, in particular, state policies toward gender relations influenced former Soviet Union ${ }^{2}$ women's willingness to migrate. It will discuss how the ideological transition from the "working women" image propagandized by the Soviet government to the current "housewives" image promoted by the Russian government have encouraged women to seek a foreign spouse. The disparity between the ideology propagandized by the government and what women experienced in real life will also be analyzed. Dissatisfied with their daily lives and men from their home countries, women have turned to foreign countries - including Japan - to improve their lives ${ }^{3}$.

This paper is based on in-depth interviews with 45 women who migrated to Japan from the early 1990s to 2005. These women are from countries such as Russia, Ukraine, Belarus, Uzbekistan, Kazakhstan, and Kyrgyzstan. They are married or formerly married to Japanese men. The fieldwork also involved participant observation in some of the women's homes, gatherings, and their communication in an online Russian-language community. The research was conducted, by the author,

Viktoriya Kim is an assistant professor at the School of Human Sciences, Osaka University, Japan. Her research interests include: global migration, in particular, labor/marriage migration of women from former Soviet Union countries to Japan, mixed-heritage children brought up in Japan and international education and international schools in Japan.

${ }^{1}$ Hereinafter - USSR.

${ }^{2}$ Hereinafter - FSU. This paper mainly refers to women from Uzbekistan, Kazakhstan, Kyrgyzstan, Ukraine, Russia and Belarus.

3 This article draws from my previously published working paper: Female Gender Construction and the Idea of Marriage Migration: Women from Former Soviet Union Countries Married to Japanese Men, No.20, Studies on Multicultural Societies, Afrasian Research Centre (Phase 2), Ryukoku University, 2013. 
between 2006 and 2012 in urban areas of Japan. The study shows that women's choices and strategies that led to migration were influenced not only by economic reasons and needs, but also by the influence of state propaganda and the influence of their families. Such propaganda in both the USSR and in the post-Soviet countries aimed to regulate the ideals of women's life course.

The implications for research can be summarized as follows: first, the Soviet state and FSU countries succeeded in the construction of women's views on their life course, marriage and family. However, though women have adhered to the promoted ideals, they often choose unexpected ways, such as marriage migration, to realize these ideals. Moreover, it became clear that women develop creative ways to increase their chances of migration. Finally, although some cases of female labor migration from the FSU countries to Japan were based on economic reasons, their subsequent marriage migration and settlement in Japan is a result of gender politics in their home countries.

\section{MARRIAGE MIGRATION AND THE CONCEPT OF “GLOBAL HYPERGAMY”}

The last two decades saw a growing body of research on female marriage migration from developing countries - the "global South" - to wealthier developed countries - North America, Europe and East Asia (Constable, 2003, 2005; Faier, 2007, 2008, 2009; Heikkila \& Yeoh, 2011; Johnson, 2007; Makhovskaya, 2003; Nakamatsu, 2003, 2005; Piper, 2007; Piper \& Roces, 2003; Suzuki, 2003, 2004, 2008, 2011; Thai, 2002, to name a few). This type of marriage migration is labeled "global hypergamy": "it is global in the sense that it involves men and women from different regions of the world. It can be considered hypergamous ... as women marrying up into a higher socioeconomic group - if we conceive of 'up' as referring to a hierarchy or a chain of geographical locations" (Constable ed., 2005, p. 10). Constable (2005) and most of the above-mentioned authors question the idea of "global hypergamy" and the general stereotype of poor women marrying wealthy men living in wealthy countries by providing a different locus - women's agency - to the discussion. In particular, these authors focus on "contradictory and paradoxical social and economic patterns that are not necessarily linked to geographic mobility” (ibid.), such as gender, race, nationality/ethnicity, geography and economic class. Moreover, there are also plenty of women who choose marriage migration for noneconomic reasons, such as out of a sense of adventure, the desire to escape narrow family relations, or because of a failed relationship back home (Piper \& Roces, 2003, p. 11), or simply to pursue love (Faier, 2007; Oxfeld, 2005). By giving voices to women engaged in marriage migration, these studies offer new insights on the perceptions of cross-border marriages and those involved.

Though many of the above-mentioned studies include female marriage migrants' experiences living in Japan (Constable, 2005; Heikkila \& Yeoh, 2011; Nakamatsu, 2003, 2005; Piper, 2007; Piper \& Roces, 2003), there are also a number of studies focusing particularly on Japanese men and foreign women. Most of the studies focus on marriage migration from such countries as the Philippines (Faier, 2008, 2009; Satake \& Da-anoy, 2006; Suzuki, 2003, 2004, 2008, 2011, etc.), China (Saihanjuna, 2011), or on Asian women as a group (Nakamatsu, 2003, 2005; Piper, 2007; Takeda, 2011, etc.), and from Russia and former Soviet Union countries (Kim, 2010, 2013a, 2013b; Kim \& Shikita, 2013; Mukhina, 2010, etc.), etc. These studies provide insight on the causes of "international marriage, ${ }^{4}$ in Japan, issues couples and their children face after marriage, and various ways of solving problems at individual and structural levels. Apart from the division by women's countries of origin, there are also attempts to theorize the concept of "international marriage" in the Japanese context. Since Japan is not a popular migrant destination compared to North America and European countries, Takeshita (2001) explains the increasing number of "international marriages" in Japan pointing at an imbalance of male and female population, weakening endogamous norms, attraction to different races and ethnicities, and physical and social proximity to foreign women and men in

\footnotetext{
${ }^{4}$ While there are a lot of arguments concerning the term denoting international marriages (kokusai kekkon) in Japan, in this paper the term "international marriage" will be utilized.
} 
sending and receiving countries. Although Takeshita's study tackles the roots of "international marriage" and the reasons that caused its increase in Japan after the World War II, it does not explain the significance of these marriages compared to intermarriages that occur within the country. In addition, it does not explain the prevailing number of women from Asian countries coming to Japan since the late 1970s when compared to women from Western countries. Further theoretical conceptualization of "international marriage" in Japan is attempted by Kamoto (2008) in her discussion of the contradictions of "global hypergamy." In her study, she elaborates on Japan's socioeconomic situation as a starting point that leads to "international marriage" in some social strata. In particular, building on the concept of marriage gradient - when older, well-educated, and successful women situated on the upper strata and less-educated and poorer men situated on the lower strata of society are less eligible on the Japan's marriage market - she explains how these women and men are likely to look for a foreign partner. Moreover, since this analysis is applicable to other sending and receiving countries, there is a high possibility for women from upper strata of less developed countries to marry men from lower strata of more developed countries. Though this concept is useful to explain the contradictions of "global hypergamy," it can be argued that with the growing availability of information, technologies, networks and transportation, "international marriages" are becoming more diversified in character. Further analysis of the marriage migrants' background and environment is necessary to explain their motives for "international marriage."

Migrants' background and environment are important in the context of marriage migration, as they allow an analysis of the impact of the internal forces that make women choose Japanese men as their marriage partners. There are several studies focusing on the political and socioeconomic situations of Asian countries - Philippines (Parreñas, 2008; Suzuki, 2003) and China (Saihanjuna, 2011) in particular - analyzing gender ideologies in these countries and Japan's image as a modern cosmopolitan country, all of which may motivate women to seek a Japanese spouse. Gender is a relational concept that forms structuring principles of histories, ideologies, economic systems and political structures, informing battles over power and privilege based on sex differences (Suzuki, 2003, p. 15). In the case of the Philippines, its gender politics tell women to work outside the home, but at the same time, it maintains the belief that a woman's proper place is inside the home (Parreñas, 2008, p. 22). In her analysis of women's experiences in the Philippines, Suzuki points to the gender surveillance and sexual violence that made women leave their home country and move to Japan. While the economic dimensions of migration are undoubtedly important to Filipina transmigrants, it should be noted that some women actually feel compelled to leave their natal families and marriages in order to work abroad and/or to (re)marry (unfamiliar) foreigners so as to get away from restrictive or distressing affective ties at home in the Philippines (Suzuki, 2003, p. 116). On the other hand, focusing on push and pull factors of marriage migration, Saihanjuna (2011) points out that the Chinese movement to liberate women that started in the 1950s led to their empowerment outside the home, but it did not have an impact on men's contribution to housework. Therefore, though the notion of egalitarian families was introduced in China, relationships inside the family remain traditional, and Chinese women are burdened by the double shift of working outside the home and taking care of the household and children. Another reason to migrate abroad is the marginalization of internal labor migrants, unemployed and divorced women, and the imbalance of the male/female population in some regions of China.

As it is clear from these studies, there are internal structural forces in Asian sending countries that facilitate marriage migration, due to Japan's image of being a "modern" country in terms of gender relationships and gender roles. However, do non-Asian marriage migrants consider Japan to be "modern"? Do they desire equality and liberation? What are their expectations towards Japanese men? Exploring gender politics in former Soviet countries and women's response to it, this article attempts to combine notions such as gender construction, marriage and migration to identify FSU women's motivations for and aspirations toward marriage migration in Japan. 


\section{GENDER POLITICS AND WOMEN'S REALITIES}

First, it is necessary to analyze the social roles of women and how femininity and the female gender were constructed in the Soviet Union and the countries that were formed after its dissolution. ${ }^{5}$ The concept of "making gender," as defined by Ortner, refers to the "subjects constructed by, and subjected to, the cultural and historical discourses within which they must operate" (Ortner, 1996, p. 1). On the other hand, she continues, we have the agent "enacting," "resisting," or "negotiating” with these cultural and historical discourses, and in doing so "making" gender (Ortner, 1996). Thus, while their ideas are constructed by the surrounding environment, individuals constantly make their own choices. This "making" may reproduce a certain society or culture, or it may produce something new, although not necessarily what the agents had intended. The politics of female gender construction in the Soviet Union and Russia greatly influenced women's willingness to migrate along with their ideas of their roles and relationships with men. Furthermore, marriage is considered to be an ultimate goal for many women in Russian society and culture. Thus, women's concerns and desires regarding their own marriages may have been influenced by their own mothers' negative experiences in marriage. It is amidst such a changing situation that young women have created their own habitus based on their mothers' experiences and social ideals.

\subsection{Gender Construction in the Soviet Union and Russia}

From 1917 to the collapse of the Soviet Union in 1991 and continuing into the shift to a market economy in Russia, expectations towards women's social roles, or the politics of female gender construction, changed based on political and economic agenda. Various authors comment on Russian women's femininity and their "willingness" to become housewives, in particular those who were born in the 1970-80s and comprise the vast majority of labor/marriage migrants. According to Visson, the dream of many Russian women is to stay at home and be looked after by strong, capable men (Visson, 2001, p. 48) and women are expected to beautify themselves as a strategy in winning the competition to attract men's interest. Holmgren points out those Russian women are often regarded by Western women as "being behind" in the sense that they agree willingly to take on the typical female roles of wife, mother and housewife (Holmgren, 1995, p. 16). Russian researchers (Barsukova, 1998; Makhovskaya, 2003; Sarsenov, 2004) liken the female gender ideology construction of the USSR and Russia to a "Cinderella" story, where women have to face hardships in the early stages of life to be eventually compensated in the future.

Looking at these images of women, it is necessary to analyze how Russian women's views on marriage and family were influenced by the state. Historical background shows how these images have changed over time. Barsukova (1998) identifies three periods defining women's social status changes. The first role model (1920-1950) was the "working woman" engaging in traditionally masculine work (see also Krylova, 2004). Two World Wars and the Russian Revolution had caused a decrease in the male population, creating a need for women to contribute in the production force. The Soviet government adopted various policies (such as the "working mother" model introduced in the 1930s) which resulted in women working full-time, rearing children with help from public agencies, families and relatives, while still doing housework (Temkina \& Rotkirkh, 2002; see also Mace, 1961). The promoted image made women consider themselves as "equal to men."

The second role model arose in the 1960s, when scientific and technological development led to the need for women who could compete equally with men in the fields of science (Barsukova, 1998). The promotion of such female models resulted in many women aspiring to attend universities. According to Aivazova (1998), in the mid-1960s 59\% of women were graduates of universities and vocational schools. That policy would start changing in the 1970s, in a context of increasing competition with the

\footnotetext{
${ }^{5}$ The majority of the women in the study are from Russia, with some of the women coming from Uzbekistan, Kazakhstan, Kyrgyzstan, Ukraine, and Belarus. While those countries are different in lifestyles, economic and political situations, according to M. Buckley (1997), the geopolitical status of post-Soviet Russia remains hegemonic. Therefore, the main focus of this study will be on Russia.
} 
capitalist world.

Moreover, the third period starts with the democratization process in the late 1980s and the thawing of diplomatic and economic links with capitalist countries, resulting in various domestic changes in the Soviet Union. The collapse was a heavy blow to the industrial sector; with the reduction in the number of jobs for men, the "working women" model was seen as a hindrance to society. This required a new ideal of women to replace "working women." According to Barsukova (1998), the government propaganda was disseminated through media that provided two ideals: the "business woman" and the "housewife." However, the "business woman" ideal was difficult to realize, since it required funding, connections and enormous efforts. Thus, the ideal of "housewife" became popular; it was supposed that any woman has a chance at achieving the "housewife" ideal since it does not require professional talents but talents "unique to women." In addition, unlike the former models, this one allegedly provides numerous benefits simply by marrying someone.

\subsection{Conflict between "Housewife" Ideal and Reality}

However, in post-Soviet Russia, marriage with a wealthy man was nearly impossible; past wars and other regional conflicts had created a continuous shortage of men, making it difficult even to find a "decent" man. The difference between the average lifespans of men and women in the Soviet Union began to grow from the 1960s (Andreyev 2003); in recent years, the average lifespan of men has dropped to 59 years; it is said that at age 65, for every 100 women there are only 46 men (Druckerman 2008). From the 1990s onward, unhealthy habits among men, such as smoking, excessive consumption of alcohol, drug addiction, as well as suicide and involvement with crime, also reduced the male population (Andreyev, 2003; Baskakova, 2005; Grogan, 2006; Predimore \& Chamlin, 2006). According to Predimore et.al. (Figure 1) it is clear that the male mortality rate from alcohol has tripled, the homicide rate quintupled, and the suicide rate doubled from the1950s to 2000s.

Figure 1: Male age-adjusted alcohol-related, homicide and suicide mortality per 100,000 residents in Russia, 1956-2002

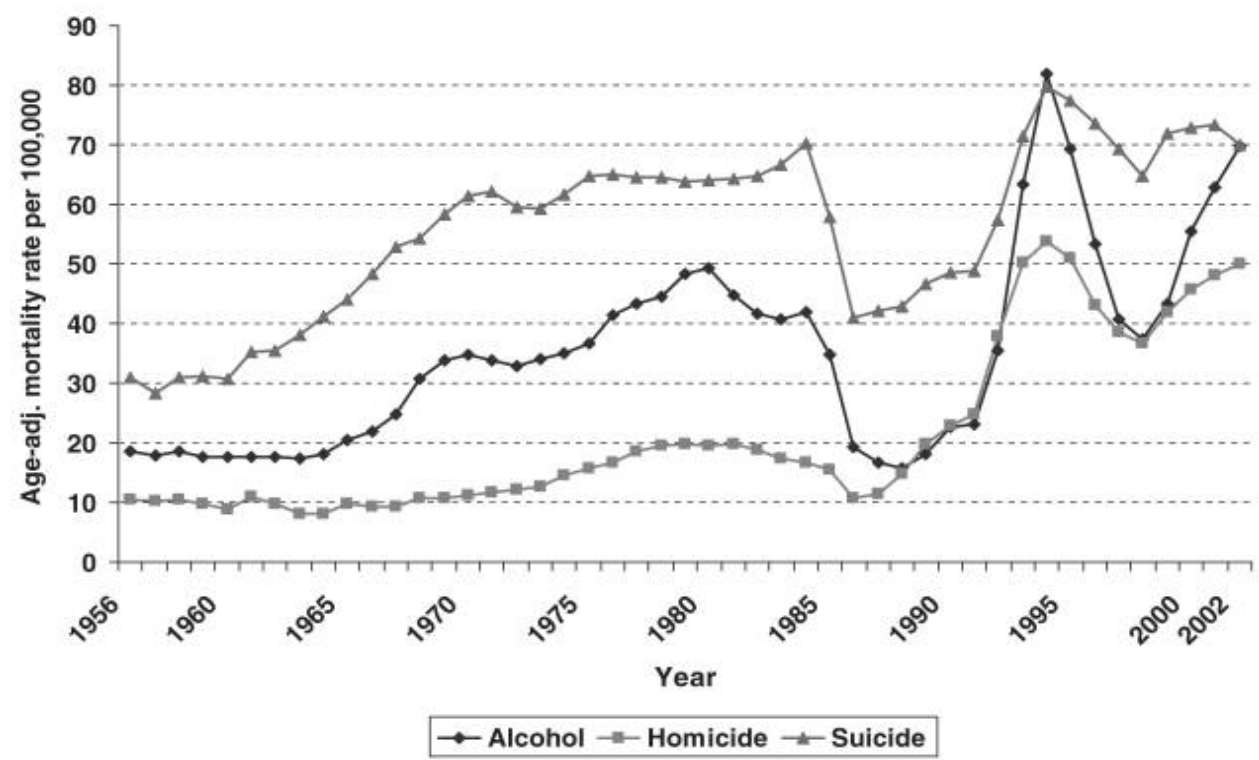

Source: Predimore et.al. 2006, p. 1723.

Another problem in realizing the "housewife" ideal was the economic instability that weakened the economic strengths of men. According to Medovoy (2006), families in the USSR needed both spouses' salaries to support their families. However, with the economic changes following its collapse 
and unemployment surging, the media and government propaganda began to present ideas of patriarchy and housewives in a positive light (Ashwin \& Bowers, 1997). Meanwhile, since the salary of men remained at the same level as before, many men could not afford having a housewife, since they could only bring home half the money required to maintain a family; thus they could not fulfill their "role" as patriarch. As a result, just as in the Soviet era, the women in Russia had no choice but to work and support their families in order to survive.

If making women willing to go back to being housewives succeeded at the ideological level in Russia, at the social level, the path to such a transition was not well prepared. Due to various economic and political issues, Russian women still strive to balance work and home roles. As a result, it became difficult for women to find men they would consider marrying, much less those that could enable them to be "housewives." Therefore, in order to realize the "goal" of becoming a housewife, Russian women began to seek new solutions abroad.

\section{DREAMING OF FOREIGN HUSBANDS}

While disintegrating family relations due to unemployment and psychological stress put women from FSU countries in a vulnerable position, the new socioeconomic and diplomatic relations also led to marriage migration becoming a possible solution for those women. According to Denisenko (2002), between 1989 and 1999, 1,040,000 people migrated from Russia to other countries. Migration types include family relocation, repatriation, and labor/marriage migration to various destinations. Discontent with the socioeconomic situation in their home countries, young women began deliberating marriage with foreign men. While there are no official statistics on women who migrate to foreign countries with the purpose of marriage, according to Filatova (2002) between 1992 and 2002, 75,000 Russian women married American men. Anashkina and Pogodina (2003) say that $60 \%$ of women who migrate for marriage are younger than 30 years old; many of these women are ethnic Russians and more than half are university graduates.

\subsection{Women from FSU Married to Japanese Men}

In recent years, the number of "international marriages" between Japanese nationals and foreigners has been continuously increasing and reached 25,934 in 2011 (Ministry of Health, Labor and Welfare's Statistical Database, 2012), where 19,022 of marriages were between a Japanese husband and a foreign wife. The most common nationalities of the wives were Chinese (8,104 couples), Filipina (4,290 couples) and South or North Korean (3,098 couples). Also, the nationality of foreign spouses of Japanese nationals began to diversify in the late 1980s, with a noted increase in marriages between citizens of FSU with Japanese, from 198 couples in $1995^{6}$ (Population Census, 1995) to about 5,000 ${ }^{7}$ as of 2012 (Ministry of Justice, 2012b), as shown in Figure 2. Most of these couples are composed of women from FSU countries and Japanese men, given the proportion of nationals from these countries living in Japan. ${ }^{8}$

\footnotetext{
${ }^{6}$ However, this number does not include marriages with women from Ukraine, Belarus, Kazakhstan, Uzbekistan, Kyrgyzstan, so the actual number is difficult to grasp.

7 According to the data compiled by the Ministry of Justice (2012), the number of citizens of former Soviet countries (mainly, Russia, Ukraine, Belarus, Kazakhstan, Uzbekistan, Kyrgyzstan) who are married to Japanese (Spouses of Japanese nationals etc., however this status is applicable for spouses of Japanese nationals, those born as the children of Japanese nationals or children adopted by Japanese nationals) was 1,771 in 2012, and the number of permanent residents was 3,671 (Ministry of Justice, 2012b).

${ }^{8}$ According to the Ministry of Justice (2012a) the overall number of men from the above-mentioned countries residing in Japan is 3,231 and the number of women is 7,151; the number of men from 20 to 55 years old is 2,341 and the number of women in the same age group is 6,179 .
} 
Figure 2: Total number of permanent residents and spouses of Japanese nationals from former Soviet countries in 2012

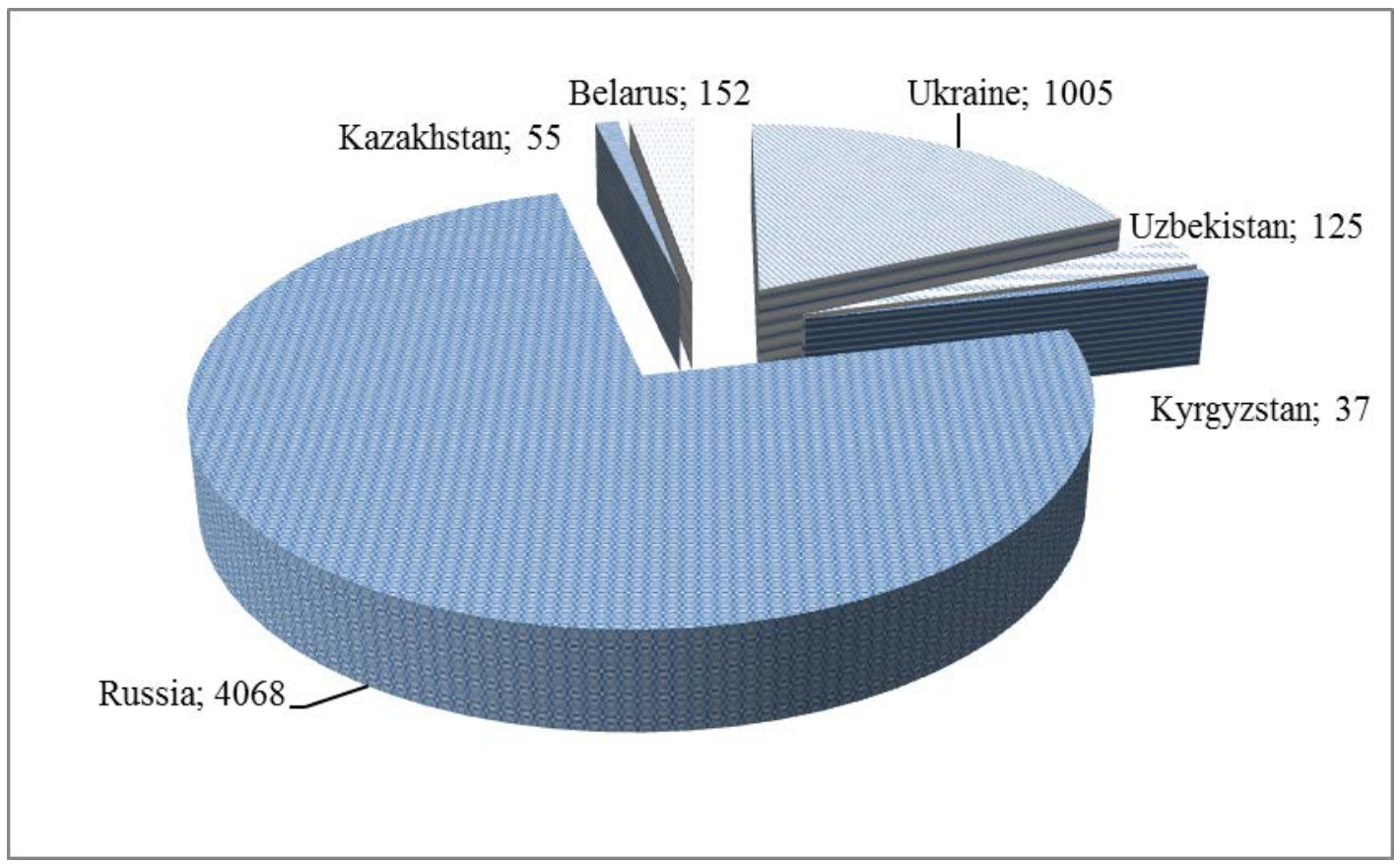

Source: Created based on "Foreign Nationals Divided by Nationality/Region based on Residence Status (Purpose of Residence)” (2012b), Ministry of Justice.

\subsection{Marriage Migration as an Escape from Gender Norms}

This section will reveal how interviewed women explain their wish to marry foreign men instead of men from their own countries. There are several trends to the comments of these women. One such common topic is their discontent with men from their home countries and their attitude towards women. For example, Antonina (late 30s) says:

You know, I think they [Russian men] ${ }^{9}$ are unreliable. (...) Let us say, if I lived with him for 15 years, there could be a possibility that he would leave me for a younger, prettier woman. Also, they take little responsibility for their children. (...) This is why now there are books being published on how to marry foreign men. If I were living in Russia, I would definitely buy that book. Because I had a goal, I definitely wanted to get married [to a foreigner].

From Antonina's interview it is clear that she is not interested in foreign men because of the economic insecurity or instability of life in Russia, but chiefly because of Russian men's attitude toward women that makes her feel insecure once she gets married and have children. Similarly, Oksana (late 30s) divorced her first Russian husband because she was not satisfied with his attitude towards her [she said there was domestic violence in their relationship], the economic instability in their marriage, and his absence from child rearing. "He was absent as a father and as a husband" she said. In addition, in her interview Oksana mentioned that her parents had also divorced, as had her sister (who later migrated to Portugal to work), and therefore her divorce was somehow not a surprise to her. Thus, the interviewed women who had a chance to marry ended up with divorce; in addition, as in Oksana's case, most of the women who participated in the study were brought up in divorced families or in the families where men were absent due to bad family relationships, alcohol addiction and other issues. These women are also discontented with economic insecurity and men's unwillingness to support their families. In the case of Mariya (early 30s), her decision to work abroad and subsequent marriage

\footnotetext{
${ }^{9}$ Author's comments indicated by [ ].
} 
migration was rooted in her economic relationship with her partner. She went to Japan to work as an entertainer and save money to start a business with her partner. This man had spent some time in prison since the age of 17, had a low education level, few skills, and was unemployed. When Mariya finished her first contract in Japan and came home, her partner was not working, and not even trying to seek employment; he was simply waiting for her money. When she found this out, she left him.

Women often complained that Russian men "have affairs," "don’t take responsibility for the family," and that women felt like they did not "have anyone to rely on," revealing that women are unsatisfied with gender or family norms in Russia. Especially emphasized by the research participants were the way female's gender is constructed and the men's attitude toward family, where women had to balance work and housework. For example, Margarita (early 30s) says:

I have had Russian boyfriends, but I never wanted to marry them. It had nothing to do with money; and it was their attitude toward women. I would have to do what they want, and they would have affairs like it is normal. They would give me little money for living expenses, and I would be the one who has to worry about earning the rest of the money, and how the family is going to live.

Some women also mention the "imbalance" of male and female population, emphasizing social problems such as alcohol and drug addiction, which leads to women being required to constantly "compete" with other women to find and keep a good husband. Marina (late 20s) explains that:

I do not think Russian men are particularly bad... There are some very good men. But many become alcoholics or do not do anything, and just complain about life. There are not many [men] who are good, young, smart and handsome. On the other hand, there are many smart and pretty Russian women, so the competition is fierce. If a woman finds a good man, she must fight against other women her entire life to keep him. In the end, there are wonderful men in Russia, but I have never met one.

Thus, these women criticized the established gender norms and since they found such a lifestyle unsatisfactory, they chose the strategy of marrying foreign men in order to escape their current situation.

\section{MEETING FOREIGN MEN}

Professional urban women "possess valuable cultural capital that allows them to implement diverse strategies. They may study abroad, become an au pair, work for international recruitment agencies, or try to marry a foreigner" (Laruelle, 2013a, p. 305; see also Belouin, 2013). The same can be said about the participants in this study. One way to have easy access to foreign men was to enroll in a university's foreign language departments (9 participants). For example, Karina (early 30s) was specializing in French and dreamed of marrying a French man; similarly, Nina (early 20s) studied in the German department; in her mind, she thought about marrying a German man. Marina, Nigora (early 30s) and Valeriya (late 20s) all specialized in Japanese language and accordingly thought about marrying Japanese men.

Aside from being foreign language students, another way to meet foreign men was through working at offices of foreign corporations or by engaging in international work. For example, Valeriya met her Japanese husband while working as a Japanese-Russian interpreter for him at a hospital. Karina taught Russian to her future Japanese husband. Maiya (late 30s) met her husband while giving tours to Japanese tourists.

For those without such opportunities, the Internet and dating services played a major role; some women actively used them to search for foreign men (7 participants). In the case of Elena (late 20s), she was interested in Japan, so she found a Japanese man through a dating agency. Yaroslavna (early 
20s) was also looking for someone to communicate with in Japanese; using Skype to find language partners, she eventually met her future husband among them.

In this research however, the most common way to meet Japanese partners among participants was the women's initial labor migration to Japan. Twenty out of 45 participants have worked in the Japanese entertainment industry as hostesses. For their employment, it was necessary to use such acquired skills as dancing, modeling and singing, and many of them met their husbands through their job. This path to earning money and marriage with a foreign man was even more attractive for many women, since by just beautifying themselves and using abilities "unique to women", they could make the idea of becoming a "housewife" more viable.

Again, while these women accepted the government model of "housewives," in order to realize this ideal, they actively utilized such resources as language studies, working in foreign companies and applying to dating services, as well as their physical skills and beauty, to effectively improve their lives. Though it can be assumed that by following the dominant discourse of patriarchal gender relations, these women lack agency and free will, asserting their "pure agency, that would encompass independently conceived aims, individual motivation, independent action and imperviousness to possible effects, would be a denial of sociality" (Parker, 2005, p. 8-9). Due to various constraining factors in the post-Soviet societies discussed above, FSU women's agency takes forms that are different from those that are shared in the Western societies, such as hierarchical and structural equalities within the concept of power relations. Nor do these forms of agency follow the path intended by the post-Soviet government policies. Thus, women exercise agency by developing various strategies to marry a foreigner and not their counterparts in their home country. They become a "housewife" in order to change their position in society while at the same time follow the ideals provided by the government.

\section{CONCLUSION}

Since the formation of the Soviet Union, the female gender had been exploited to accommodate political, economic and social situations. Although gender equality was propagandized, women had to balance home and work. Meanwhile, the unemployment level in post-Soviet countries required "housewives," not "working women." As a result, younger women from former Soviet countries were brought up to embrace a "housewife" ideal. Thus, unlike Asian marriage migrants, FSU women seek "traditional" marriage with patriarchal gender roles where men work outside the home and women work inside.

However, not many men in FSU countries can provide women with the promoted "housewife" lifestyle; national policy has given them the goal of "marriage" but not the means to achieve it. At the same time, new diplomatic ties and a more open world meant that these women could now potentially find a husband in the global marriage market. For these women, marriage migration became a method of overcoming difficulties in living and allowing the reproduction of the "housewife" ideal through the institution of marriage. Japan became one of the "ideal" destinations for marriage migration with its labor migration possibilities, where women could apply not only such acquired capacities as language and other professional skills, but also their innate female qualities to find an appropriate partner.

Thus, in the case of FSU women, the interaction between nation and individual was not limited by the boundaries of a country, but functioned on a global scale. Women were able to utilize their available resources, especially physical attractiveness and skills, foreign language education and the popularization of the dating services, to seek new partners. This shows that a globalized relationship between social structure and individuals does not always result in domination by the social structure and subjugation of the individual; globalization also creates new choices for individuals, and generates possibilities for them to be creative. 


\section{REFERENCES}

Aivazova, S. (1998). От теории к практике: “контракт работающей матери” (From Theory to Practice: “Working Mother's Contract”). Русские женщины в лабиринте равноправия: очерки политической теории и истории (Russian Women in the Labyrinth of Equality: Essays on Political Theory and History). Retrieved from http://www.owl.ru/win/books/rw/index.htm [Accessed 2011-05-10].

Anashkina, G.P., \& Pogodina S.A. (2003). Брак с иностранцем как новая модель адаптации российских женщин в условиях переходного общества (Marriage with a Foreigner as a New Model of Adaptation of Russian Women in the Transitional Society). Retrieved from http://www.ethnonet.ru/etnografiya/brak-s-inostrancem-kak-novaja-model-adaptacii/ [Accessed 2011-01-20].

Andreyev, E.M. (2003). Почему в России так велик разрыв в продолжительности жизни мужчин и женщин (Why is There Such a Huge Gap in Men and Women’s Average Lifespan?). Demoscope Weekly, 131-132. Retrieved fromhttp://demoscope.ru/weekly/2003/0131/analit05.php [Accessed 2008-10-18].

Ashwin, S., \& Bowers, E. (1997). Do Russian Women Want to Work? In M. Buckley (Ed.), Post-Soviet Women: From the Baltic to Central Asia (pp. 21-37). Cambridge: Cambridge University Press.

Barsukova, S. Y. (1998). ‘Золушки’ советской и постсоветской эпохи (“Cinderellas” of Soviet and Post-Soviet Periods). Rubej (Anthology of Social Research), 12, 92-105.

Baskakova, M.E. (2005). Содействие в достижении равенства мужчин и женщин и расширение прав и возможностей женщин (Contribution to Gender Equality and Enlargement of Women's Rights and Scopes). Demoscope Weekly, 219-220. Retrieved from http://www.demoscope.ru/weekly/2005/0219/analit01.php [Accessed 2008-10-14].

Belouin, S. (2013).Projects and Migratory Strategies of Women Belonging to the Tashkent Intelligentsia. In M. Laruelle (Ed.), Migration and Social Upheaval as the Face of Globalization in Central Asia (pp. 377-395). Leiden, Boston: Brill.

Buckley, M. (1997). Victims and Agents: Gender in Post-Soviet States. In M. Buckley (Ed.), Post-Soviet Women: From the Baltic to Central Asia (pp. 3-16). Cambridge: Cambridge University Press.

Constable, N. (2003). Romance on a Global Stage: Pen Pals, Virtual Ethnography, and "Mail Order" Marriages. Berkley and Los Angeles: University of California Press.

Constable, N. ed. (2005). Cross-Border Marriages: Gender and Mobility in Transnational Asia. Philadelphia: University of Pennsylvania Press.

Denisenko, M. (2002). Эмиграция из России по данным зарубежной статистики (Emigration from Russia Based on Overseas Statistics). Demoscope Weekly, (65-66). Retrieved from http://www.demoscope.ru/weekly/2002/065/tema01.php [Accessed 2008-10-21].

Druckerman, P. (2008). Lust in Translation: Which Country Has the Highest Rates of Infidelity? Retrieved from http://www.alternet.org/sex/81022 [Accessed 2008-04-15].

Faier, L. (2007). Filipina Migrants in Rural Japan and Their Professions of Love. American Ethnologist, 34 (1): 148-162. 
Faier, L. (2008). Runaway Stories: The Underground Micromovements of Filipina Oyomesan in Rural Japan. Cultural Anthropology, 23 (4): 630-659.

Faier, L. (2009). Intimate Encounters: Filipina Women and the Remaking of Rural Japan. Berkeley and Los Angeles: University of California Press.

Filatova, N. (2002, September 24). Уж замуж за рубеж (Marrying Abroad). Itogi.ru, 38/238. Retrieved from http://www.itogi.ru/archive/2002/38/100604.html [Accessed 2008-10-22].

Grogan, L. (2006). Alcoholism, Tobacco, and Drug Use in the Countries of Central and Eastern Europe and the Former Soviet Union. Substance Use \& Misuse, 41, 567-571.

Heikkilä, E. K., \& Yeoh, B. S.A. (2011). International Marriages in the Time of Globalization. New York: Nova Science Publishers, Inc.

Holmgren, B. (1995). Bug Inspectors and Beauty Queens: The Problems of Translating Feminism into Russian. In E. E. Berry (Ed.), Postcommunism and the Body Politic (pp. 15-31). New York: New York University Press.

Johnson, E. (2007). Dreaming of a Mail-Order Husband: Russian-American Internet Romance. Durham and London: Duke University Press.

Kamoto, I. (2008). Kokusai kekkon-ron!? Gendai-hen (International Marriage Theory!? Modern Edition). Hōritsu Bunkasha.

Kim, V. (2010). Conflict and Strategies in Cross-Border Marriages: The Experiences of Women from the Former Soviet Union and Japanese Men. Paper presented at the 3rd Next-Generation Global Workshop - Migration: Global Reconstruction of Intimate and Public Spheres, Kyoto University, Japan.

Kim, V. (2013a). Female Gender Construction and the Idea of Marriage Migration: Women from Former Soviet Union Countries Married to Japanese Men. Working Paper Series: Studies on Multicultural Societies of Afrasian Research Centre, Ryukoku University Phase 2, 20. Retrieved from http://afrasia.ryukoku.ac.jp/english/publication/upfile/wp20.pdf[Accessed 2013-10-09].

Kim, V. (2013b). "International Marriage” as a Symbolic Exchange of Capital: The Case of Women From the Former Soviet Union Married to Japanese Men. Osaka Daigaku Daigakuin Ningen Kagaku Kenkyuka Kiyo, 39, 217-235.

Kim, V., \& Shikita, K. (2013). Nihon-no gakkō-ni kayowaseru kokusai kekkon katei (Iternational Couples with Children Studying in Japanese Schools). In K. Shimizu, B.A. Yamamoto, I. Kaji, \& K. Hayashizaki (Eds.), “Ōkan-suru hitobito”-no kyōiku senryaku:gurōbaru shakai-o ikiru kazoku-to kōkyōiku-no kadai (The educational strategies of transnational families: The challenges of public education for families living in a global society) (pp. 123-139). Tokyo: Akashi Shoten.

Kivisto, P. J., \& Faist, T. (2010). Beyond a Border: The Causes and Consequences of Contemporary Immigration. Thousand Oaks, CA: Pine Forge Press.

Krylova, A. (2004). Stalinist Identity from the Viewpoint of Gender: Rearing a Generation of Professionally Violent Women-Fighters in 1930s Stalinist Russia. Gender \& History, 16 (3): $626-653$. 
Laruelle, M. (2013a). Impact on Gender Relations: Masculinity and Femininity in Flux. Introduction. In M. Laruelle (Ed.), Migration and Social Upheaval as the Face of Globalization in Central Asia (pp. 303-306). Leiden, Boston: Brill.

Laruelle, M. (2013b). Introduction. In M. Laruelle (Ed.), Migration and Social Upheaval as the Face of Globalization in Central Asia (pp. 5-15). Leiden, Boston: Brill.

Mace, D. R. (1961). The Employed Mother in the U.S.S.R. Marriage and Family Living (November), 330-333.

Makhovskaya, O. (2003). Браки с иностранцами: игры без правил (Marriage with Foreigners: Games without Rules). Zhenshina Plus, 1. Retrieved from http://www.owl.ru/win/womplus/2003/01_10.htm [Accessed 2009-05-02].

Makhovskaya, O. (2005). Соблазн эмиграции или Женщинам, отлетаюшим в Париж: психологические эссе (Temptation of Emigration or to Women Departing to Paris: Psychological Essays). Moscow: Perse.

Medovoy, I. (2006, September 29). Мужчина рождается свободным. Потом он женится... (Man is Born Free. Than He Marries...). Tribuna. Retrieved from http://demoscope.ru/weekly/2006/0259/gazeta02.php [Accessed 2008-10-11].

Ministry of Health, Labour and Welfare Statistical Database. (2012). Fūfu no kokuseki betsuni mita nenji betsu konnin kensū (Annual Transition in Number of Marriages by Nationality of Spouse). Retrieved from http://www.e-stat.go.jp/SG1/estat/List.do?lid=000001101888\#TOP [Accessed 2013-01-21].

Ministry of Justice. (2012a). Kokuseki/chiiki betsu nenrei/danjo betsu zairyū gaikokujin (Foreign Residents by Nationality/Region and Age/Sex). Retrieved from http://www.e-stat.go.jp/SG1/estat/List.do?lid=000001111183 [Accessed 2013-08-21].

Ministry of Justice. (2012b). Kokuseki/chiiki betsu zairyū shikaku (zairyūmokuteki) betsu zairyū gaikokujin (Foreign Residents by Nationality/Region and Status of Residence (Purpose of Residence)). Retrieved from http://www.e-stat.go.jp/SG1/estat/List.do?lid=000001111183 [Accessed 2013-08-21].

Mukhina, V. (2010). Who is the Threat? Influence of Migration on the Intimate Life of Migrant Wives in Cross-National Couples: A Case of Russian-Speaking Wives in Japan. Paper presented at the 3rd Next-Generation Global Workshop - Migration: Global Reconstruction of Intimate and Public Spheres, Kyoto University, Japan.

Nakamatsu, T. (2003). International Marriage through Introduction Agencies: Social and Legal Realities of “Asian” Wives of Japanese Men. In N. Piper \& M. Roces (Eds.), Wife or Worker? Asian Women and Migration (pp. 181-201). Lanham, Maryland: Rowman \& Littlefield Publishers, Inc.

Nakamatsu, T. (2005). Complex Power and Diverse Responses: Transnational Marriage Migration and Women's Agency. In L. Parker (Ed.), The Agency of Women in Asia (pp. 158-181). Singapore: Marshall Cavendish International.

Ortner, S. B. (1996). Making Gender: The Politics and Erotics of Culture. Boston: Beacon Press.

Oxfeld, E. (2005). Cross-Border Hypergamy? Marriage Exchanges in a Transnational Hakka Community. In N. Constable (Ed.), Cross-Border Marriages: Gender and Mobility in Transnational Asia (pp. 17-33). Philadelphia: University of Pennsylvania Press. 
Parker, L. (2005). Introduction. In L. Parker (Ed.), The Agency of Women in Asia (pp. 1-25). Singapore: Marshall Cavendish International.

Parreñas, R.S. (2008). The Force of Domesticity: Filipina Migrants and Globalization. New York and London: New York University Press.

Piper, N. (1997). International Marriage in Japan: “Race” and “Gender” Perspectives.” Gender, Place \& Culture: A Journal of Feminist Geography, 4 (3).

Piper, N., \& Roces, M. (2003). Wife of Worker: Asian Women and Migration. New York: Rowman \& Littlefield Publishers, Inc.

Population Census. (1995). Otto no kokuseki (42 kubun), tsuma no kokuseki (42 kubun) betsu fūfusū - zenkoku (Number of Spouses Divided by Nationality of Husband (42 categories), Nationality of Wife (42 categories) - Country Overall). Gaikokujin ni kansuru tokubetsu shūkei kekka, 9, 370-371.

Predimore, W. A., \& Chamlin, M. B. (2006). A Time-series Analysis of the Impact of Heavy Drinking on Homicide and Suicide Mortality in Russia, 1956-2002. Addiction, 101, 1719-1729.

Saihanjuna. (2011). Kokusai Idō Jidai-no Kokusai Kekkon: Nihon-no Nōson-ni Totsuida Chūgokujin Josei (Intermarriage in the Global Immigration Era: Chinese Wives Settling in Rural Japan). Tokyo: Keisō Shobō.

Sarsenov, K. (2004). Брачная миграция на ТВ экране: сказка и “реалити” (Marriage Migration on TV: Fairytales and "Reality"). Гендер по-русски: преграды и предель (Gender in Russian: Barriers and Limitations) (International Science Seminar, Tver).

Satake, M., \& Da-anoy, M.A. (2006). Firipin-nihon kokusai kekkon: ijūu-to tabunka kyōsei (Filipina-Japanese Intermarriages - Migration, Settlement, and Multicultural Coexistence). Tokyo: Mekong.

Suzuki, N. (2003). Battlefields of Affection: Gender, Global Desires, and the Politics of Intimacy in Filipina-Japanese Transnational Marriages. (Unpublished doctoral dissertation). University of Hawaii, Honolulu.

Suzuki, N. (2004). Inside the Home: Power and Negotiation in Filipina-Japanese Marriages.” Women's Studies, 33: 481-506.

Suzuki, N. (2008). Between Two Shores: Transnational Projects and Filipina Wives in/from Japan.” In D. B. Willis \& S. Murphy-Shigematsu (Eds.), Transcultural Japan: At the Borderlands of Race, Gender, and Identity (pp. 65-85). London and New York: Routledge.

Suzuki, N. (2011). Love Triangles: Filipinos, Japanese, and the Shifting Locations of American Power. In K. Fujiwara \& Y. Nagano (Eds.), The Philippines and Japan in America's Shadow (pp. 259-281). Leiden, Boston: Brill.

Takeda, S. (2011). Mura-no kokusai kekkon saikō: kekkon idō josei-to nōson-no shakai henyō (Transnational Marriage in Rural Japan: Reconsidered - Adaptation and Social Transformation). Tokyo: Mekong.

Takeshita, S. (2001). Kokusai kekkon-no shakaigaku (Sociology of International Marriage). Tokyo: Gakubunsha. 
Temkina, A. A., A., \& Rotkirkh. (2002). Советские гендерные контракты и их трансформация в современной России (Soviet Gender Contracts and Their Transformation in Contemporary Russia). Sotsiologicheskie Issledovaniya (Sociological Researches), 11: 4-15.

Thai, H. C. (2002). Clashing Dreams: Highly Educated Overseas Brides and Low-Wage U.S. Husbands. In B. Ehrenreich \& A. R. Hochschild (Eds.), Global Woman: Nannies, Maids, and Sex Workers in the New Economy (pp. 230-253), New York: Metropolitan Books.

Visson, L. (2001). Wedded Strangers: The Challenges of Russian-American Marriages. New York: Hippocrene Books. 